\title{
Potency and Characteristics of Bali Cattle Twin Birth
}

\author{
Anastasia Sischa Jati Utami* and I Nyoman Suyasa \\ Assessment Institute for Agricultural Technology (AIAT), Jl By Pass Ngurah Rai Pesanggaran, \\ Denpasar, Bali, Indonesia Telp. (0361) 720498 \\ *Corresponding author email: siskajati@yahoo.com
}

\begin{abstract}
Cattle twin birth is a rare occurrence that might be due to two factors, natural factors or external interventions such as the use of hormones. This study was aimed to determine to what extent Bali cattle were potential to deliver twin birth. Natural twin birth observation was conducted by survey method and data service while for super ovulation was conducted on 6 cows that never gave birth to twins. The Intervention method used a variety of hormonal preparations started with installing CIDR implant on day 1 to day 7 of CIDR removal of the implant, injecting $1 \mathrm{cc}$ of GnRH hormone injections intra-muscular on day 9, injecting $800 \mathrm{mg}$ intra-muscular PMSG on day 20, injecting 2 cc PGF2alpha intra-muscular on day 22, then conducting artificial insemination after lust symptoms appeared after day 24 applicated 3 times. Control treatments were applied on 6 cattle without hormone injection. Data were analyzed descriptively. The survey data showed Bali cattle twin birth in Bali Island was 64 heads of parent population in Bali from a total of 203,727 breeding or 31.9\%, but cattle with hormone manipulation delivered $30 \%$ of the total treatment although no previous twin birth history was recorded. Conclusively, manipulation of external stimuli such as hormones gained good response although no genetic ever gave birth to twins.
\end{abstract}

Key words: bali cattle, twin born naturally, hormone treatment

\begin{abstract}
Abstrak. Sapi lahir kembar adalah kejadian langka yang mungkin disebabkan karena dua faktor, faktor alam atau intervensi eksternal seperti penggunaan hormon. Penelitian ini bertujuan untuk menentukan sejauh mana sapi Bali memiliki potensi untuk memberikan kelahiran kembar. Pengamatan kelahiran kembar alami dilakukan dengan metode survei dan layanan data sedangkan untuk kegiatan super ovulasi dilakukan pada 6 sapi yang tidak pernah punya riwayat melahirkan anak kembar sebelumnya. Metode Intervensi digunakan berbagai persiapan hormonal mulai dengan pemasangan CIDR implant pada hari 1 sampai hari 7 CIDR implant diangkat, suntikan hormon GnRH sebanyak 1cc intra-muscular pada hari 9, dilanjutkan dengan penyuntikan 800 mg PMSG intra-muscular pada hari 20, selanjutnya suntikan PGF2alpha sebanyak 2cc intra-muscular pada hari 22, kemudian inseminasi buatan dilakukan seelah gejala birahi muncul pada hari 24 dan diinseminasi sebanyak 3 kali. Sedangkan perlakuan kontrol yang diterapkan pada 6 sapi tanpa injeksi hormon. Data dianalisis secara deskriptif. Data hasil survei menunjukkan sapi Bali kelahiran kembar di Pulau Bali sebanyak 64 induk melahirkan kembar dari total 203.727 atau 31,9\%, tetapi dengan memanipulasi hormon pada ternak menghasilkan 30\% lahir kembar dari keseluruhan treatment meskipun tidak ada tercatat riwayat kelahiran kembar sebelumnya. Kesimpulan dengan manipulasi rangsangan eksternal seperti hormon ternyata memperoleh respon yang baik meskipun tidak ada genetik pernah melahirkan anak kembar.
\end{abstract}

Kata kunci: sapi bali, kelhiran kembar, perlakuan hormon

\section{Introduction}

Bali cattle have several advantages among other local livestock so much in demand to be maintained. Bali cattle are well-known in Bali itself since Balinese farmer both fields and gardens will maintain Bali cattle. Besides, resistance to extreme environment makes Bali cattle superior meat producer (carcass) (Suyasa et al., 2011). Many other areas breeding Bali cattle such as Sulawesi, Nusa Tenggara and East Nusa Tenggara are in great demand because of high fertility rate (Guntoro, 2004), and the demand is increasing year to year. Of 100 thousand heads quota prepared annually, Bali is only able to meet about 60-70 thousand head per year (Disnak Bali, 2013). This indicates that the market opportunity for Bali cattle is still very large, along with business development of 
local beef cattle area (Suryana, 2009), which is a challenge and an opportunity for farmers to increase productivity. To increase productivity (production and reproduction), various attempts have been made and multiple births in cattle become an alternative choice, by increasing one birth to twin birth. The objective of this research was to determine the potential of Bali cattle that gave twin birth in Bali and distribution locations.

\section{Materials and Methods}

The research used exploration method (determination of the region/location) to obtain locations or map of a population with multiple births, and descriptive methods to get a true picture of an object (Suparmoko, 1998). Purposive sampling was used to determine 8 districts and one municipality in Bali, further exploration was done by the method of data collection in collaboration with provincial and district livestock services in which the activities carried out. Data collection techniques included interviews, recording and observation to obtain primary and secondary data. Six cows were assigned to hormones superovulation treatment and 6 cows without hormone treatment served as a control. Superovulation was conducted using the installation of CIDR implant hormone (progesterone $1.38 \mathrm{~g}$ ) intrauterine, and administration of hormone GnRH (Fertagyl тм, Intervet International BV, Boxmerr Holand) containing $100 \mu \mathrm{g}$ per $\mathrm{ml}$ of pure gonadorellin, given lutaprost (PGF2alpha) and Folligon hormone (PMSG) $800 \mathrm{mg}$, with intermittent hormone system and synchronize estrus.

Six Bali cows underwent CIDR implant installation (vaginal insert) on day 0 (D-9), then (D-2) CIDR implants were removed, on day 9 (DO) injection of GnRH hormone $1 \mathrm{cc}$ intramuscular, day 20 (D10) PMSG hormone injections of $800 \mathrm{mg}$ intra-muscular, day 22 (D12) PGF2alpha injection of 2 cc intramuscular, Al (artificial insemination) were performed after lust symptoms appeared on day 24 (D14-15) for 3 times every morning and afternoon. Superovulation hormone treatment was accompanied by vitamin E (Vigantol E) to improve the reproductive system. Whereas, Six cows in control treatment were not given anything prior to $\mathrm{Al}$ (artificial insemination).

\section{Results and Discussion}

Table 1. shows that twin births occurred in 8 district and 21 sub districts, with the highest occurrence was 22 multiple births in Jembrana district $(33.85 \%)$, followed by 7 twins each in Tabanan, Buleleng, Gianyar and Bangli (10.77\%), 6 and 5 multiple births in Klungkung

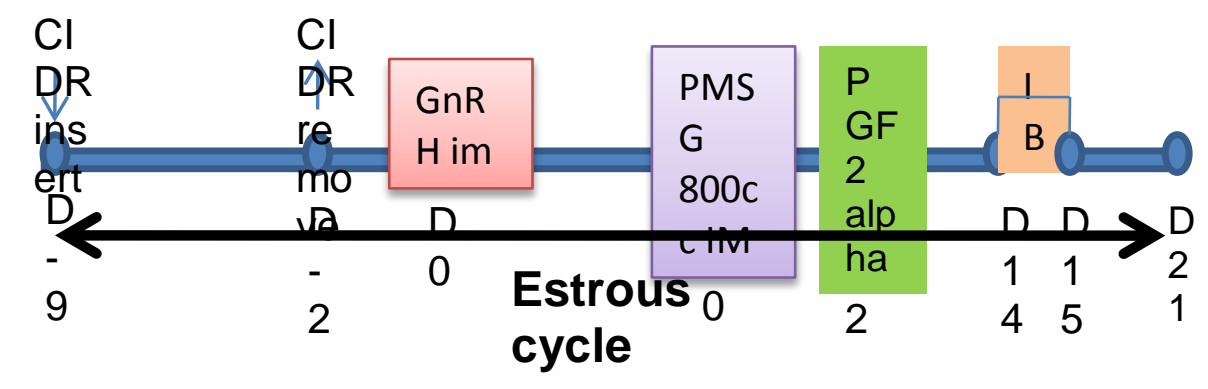

Figure 1. Estrous cycle

Explanation: $D=$ Day; $C I D R=$ Controlled Internal Drug Release; $P G=$ Prostaglandin; $P M S G=$ Pregnant Mare Serum Gonadotropin; IB= Insemenation; GNRH= Gonadotropin Releasing hormon 
(9.23\%) and Badung (7.69\%), respectively, the least was 4 twins in Karangasem (6.15\%).

In Karangasem District, 3 and 1 twin births occurred Bebandem and Sidemen subdistricts, respectively. Badung District consisted of 2 subdistricts, Mengwi and Abiansemal. In Jembrana regency, twin births occurred in 5 districts namely subdistrict Pekutatan (3), Negara (7), Jembrana (3), Melaya (7) and Mendoyo (2). Twin births in 3 districts of Tabanan regency were in Baturiti (5), Marga (1) and Tabanan (1), while Buleleng district only had two area with twin birth, Gerokgak (6) and Seririt (1). Twin birth was also found in 2 subdistricts of Klungkung, Banjarangkan (3) and Klungkung (2); in 3 subdistricts of Bangli, Susut (1), Tembuku (3), and Bangli (3); and in two subdistricts of Gianyar, Gianyar (2) and Payangan (3).
In Table 1. Also shows that the sexes in cattle born twins were 3 types, 22 male-male (33.85\%), 29 female-female (44.62\%), and 14 male-female (21.54\%). Both male-male and female-female twin with a single offspring was capable of reproduction, while multiple births with male-female sex will lead to infertile (sterile), so it cannot be a parent and only to be cut (Puslitbangnak, 2008).

Percentage of living twin birth was $91.15 \%$ from 100 cows (200 calves) or only $8.85 \%$ mortality. These data also showed that the percentage of living multiple births was high and almost equal to that of single births. Percentage of mating in the afternoon (72.31\%) was strongly influenced by time to observe cattle's lust and the Al officer chance to perform Al mating only in the afternoon after finishing their work in Department of Livestock

Table 1. Incident twin birth and sex from Bali cattle in Bali

\begin{tabular}{|c|c|c|c|c|c|c|c|}
\hline \multirow[b]{2}{*}{ No } & \multirow[b]{2}{*}{ District } & \multirow[b]{2}{*}{ Sub District } & \multirow{2}{*}{$\begin{array}{l}\text { Total Number } \\
\text { Twin Birth }\end{array}$} & \multicolumn{3}{|c|}{ Sex } & \multirow{2}{*}{$\begin{array}{c}\text { Live } \\
\text { Percentage } \\
\text { per District }\end{array}$} \\
\hline & & & & $\begin{array}{l}\text { Male- } \\
\text { Male }\end{array}$ & $\begin{array}{l}\text { Male- } \\
\text { Female }\end{array}$ & $\begin{array}{l}\text { Female- } \\
\text { Female }\end{array}$ & \\
\hline \multirow[t]{5}{*}{1} & Jembrana & Pekutatan & 3 & & 1 & 2 & 100 \\
\hline & & Negara & 7 & 1 & & 4 & \\
\hline & & Jembrana & 3 & 2 & & 1 & \\
\hline & & Melaya & 7 & 1 & 2 & 4 & \\
\hline & & Mendoyo & 2 & 1 & & 1 & \\
\hline \multirow[t]{3}{*}{2} & Tabanan & Baturiti & 5 & 2 & & 3 & 94 \\
\hline & & Marga & 1 & & 1 & & \\
\hline & & Tabanan & 1 & 1 & & & \\
\hline \multirow[t]{2}{*}{3} & Buleleng & Gerokgak & 6 & 1 & 3 & 2 & 90.91 \\
\hline & & Seririt & 1 & & 1 & & \\
\hline \multirow[t]{2}{*}{4} & Klungkung & Klungkung & 2 & 1 & & 1 & 100 \\
\hline & & Banjarangkan & 3 & & 1 & 2 & \\
\hline \multirow[t]{3}{*}{5} & Bangli & Bangli & 3 & 1 & 1 & 1 & 71.43 \\
\hline & & Tembuku & 3 & & 1 & 2 & \\
\hline & & Susut & 1 & 1 & & & \\
\hline \multirow[t]{2}{*}{6} & Gianyar & Gianyar & 4 & 3 & & 1 & 80 \\
\hline & & Payangan & 3 & 2 & & 1 & \\
\hline \multirow[t]{2}{*}{7} & Karangasem & Bebandem & 3 & & 1 & 2 & 92.85 \\
\hline & & Sidemen & 1 & & & 1 & \\
\hline \multirow[t]{4}{*}{8} & Badung & Mengwi & 3 & 2 & 1 & & 100 \\
\hline & & Abiansemal & 3 & 1 & 1 & 1 & \\
\hline & Total & & 65 & 22 & 14 & 29 & \\
\hline & Percentage $\mathrm{fr}$ & twins birth (\%) & & 33.85 & 21.54 & 44.62 & $91.15 *$ \\
\hline
\end{tabular}

*Average live percentage of twin birth per District 
Table 2. Quantity of Twin Birth, Number of matting, time and mating system

\begin{tabular}{llccccccc}
\hline \multirow{2}{*}{ District } & \multicolumn{2}{c}{ Twin Birth (Head) } & \multicolumn{2}{c}{ Number of Mating } & \multicolumn{2}{c}{ Time for Mating } \\
\cline { 2 - 8 } & & 1 time & $>1$ time & 1 time & $>1$ time & morning & afternoon & evening \\
\hline 1 & Karangasem & 4 & & 4 & & 3 & 1 & \\
2 & Badung & 6 & & 6 & & 1 & 1 & 4 \\
3 & Jembrana & 21 & $1 *$ & 20 & 2 & 5 & 2 & 15 \\
4 & Tabanan & 7 & & 7 & & & & 7 \\
5 & Buleleng & 7 & & 5 & 2 & & 1 & 6 \\
6 & Klungkung & 5 & & 5 & & & & 5 \\
7 & Bangli & 7 & & 7 & & 3 & & 4 \\
8 & Gianyar & 7 & & 7 & & 1 & & 47 \\
\hline & Total & 64 & 1 & 61 & 4 & 13 & 5 & 47 \\
\hline
\end{tabular}

*Jembrana District Case only delivers birth twice

Sub-district/district.

Table 2 showed that data of animal mating from 65 cows giving twin birth, 37 (56.92\%) were naturally mated and 28 (43.08\%) used artificial insemination ( $\mathrm{Al})$, and all $\mathrm{Al}$ officers in Bali districts used straw from UPT Disnak Bali Province in Baturiti. Only 2 natural mating occurred in Bali farms while artificial insemination (Al) for multiple births were found in some areas such as Badung District (6 occurrence) and Tabanan District (7 occurrence) had twin birth from artificially inseminated cows (100\%). As for the 6 other districts were either by natural mating or Al. From data collected there was one cow give birth to twins repeatedly. Data showed most of mating process in the evening time or about 47 cows or about $73 \%$ for incidence mating process in the morning 13 cows or about $20 \%$ and for incidence mating in the afternoon 5 cows or about $7 \%$.

\section{Outside Stimulation}

Treatment with external stimuli on the cow that never produce the data obtained twins. On the control treatment, the distance between estrous and conception was not available because it did not include the provision of vitamin. The data recorded were only the distance from estrus to conception up to \pm 12 hours after the first estrous symptom appeared. At the super ovulation treatment, showed 1 cow not give response, because the cow was still in lactation stage. From Table 3. can be showed about $80 \%$ conception rate in the super-ovulation treatment was much higher than control that was only $25 \%$ conception by artificial insemination. This data showed that the effect of GnRH and PGF was significant to improve the high conception rates. It also affected the number of non-return rate. In the treatment, $80 \%$ cows did not show estrus symptom returned and only $20 \%$ of total number of 6 cows showed estrous symptoms, while the control was only $25 \%$ of number of cows that showed on estrous symptom, the rest showed symptoms of estrus again in the next month and naturally mated again. During the pregnancy, no cows showed any symptoms of abortion until the end of pregnancy.

Factors contributing to the success of super ovulation include the existence of intrinsic and extrinsic factors. Intrinsic factors including the physiological condition of the cow, the presence of dominant follicle function, and decreasing number of embryos. Extrinsic factors include poor quality of feed given during treatment and the cows are still in the period of lactation. The possibility of less amount of semen can also cause the failure of super ovulation. This study, performed 3 times using 3 straw Al for cattle treatment, whereas in the control cows only done 1 time Al with 1 straw, 
Table 3. Superovulation response parameters of the study

\begin{tabular}{lcc}
\multicolumn{1}{c}{ Parameter } & Treatment & Control \\
\hline Cattle showed estrous (\%) & 83 & 100 \\
The distance between estrous (hours) & 35.6 & 0 \\
The distance between treatment and conception (hours) & 50.2 & 0 \\
Conception rate (\%) & 80 & 25 \\
The number of insemination per conception & 3 & 1 \\
Length of estrous cycle (days) & 14 & 19.75 \\
Incidence of abortion in trimester I & 0 & 0 \\
Incidence of abortion in trimester II & 0 & 0 \\
Incidence of abortion in trimester III & 0 & 0 \\
NR (Non Return Rate) & 80 & 25 \\
\hline
\end{tabular}

Description: The primary data taken from farmers

Table 4. Result of super-ovulation treatment

\begin{tabular}{|c|c|c|c|c|c|}
\hline \multirow{2}{*}{ Parameter } & \multirow{2}{*}{$\begin{array}{l}\text { Quantity } \\
\text { (head) }\end{array}$} & \multicolumn{2}{|c|}{ Gender (head (\%) } & \multicolumn{2}{|c|}{ Average of birth weight $(\mathrm{kg}$} \\
\hline & & Male & Female & Male & Female \\
\hline Cows treated & 6 & & & & \\
\hline Gave birth triplets & 2 & $4(66.66)$ & $2(33.33)$ & 10 & 8 \\
\hline Gave birth twins & 0 & 0 & & & \\
\hline Give birth single & 4 & $2(50.00)$ & $2(50.00)$ & 15.5 & 14.4 \\
\hline
\end{tabular}

as is commonly done farmers. The length of estrous cycle in the treatment is 14 days because of the effect synchronization using PGF and GnRH to facilitate the application of PMSG. This hormone also improve the reproductive system for cows that having longer anestrous cycle. The data showed that from 6 cows, two gave birth to 3 calves (triplet), and the other 4 only 1 calf each. Results of hormonal treatment indicated twin produced 6 calves with each male-male-male and the other one is malefemale-female as presented in Table 4.

According to Yasa (2001), average weight of male and female Bali calves is $16 \mathrm{~kg}$ and $15 \mathrm{~kg}$, respectively. The lower weight in female was due to three calves per parturition so the nutrients from parents were rationed for three. Economic analysis on the use of hormones for super ovulation treatment showed that this treatment was still expensive. The cost of hormones treatment per head of cattle was approximately 873 rupiah. Farmers are still reluctant to use this technology because of the lack of understanding about super-ovulation and the high price.
Twin incidence will be highly influenced by the twin genes that exist in the parent and in male, the other thing is the possibility of ovulation more of 1 parent who allows the double fertilization. According to Research-

Department of Agriculture (2009) in common with natural mating showed a greater incidence of twins born than the Al but when seen by districts then to Badung, Tabanan and Klungkung have the opposite phenomenon, whereby mating Al shows the odds of multiple births more. According to Arifin Bashir (2009) Al can also be used to obtain multiple births in calves, which is important to be there more of one egg each ovulation.

\section{Conclusions}

Bali cattle have considerable potential to produce twins although usually only one birth. Twinning in Bali cattle could was possible through natural factors and external factors namely external hormonal intervention. Provision of external hormonal treatment to stimulate twin birth was not limited to cows previously gave birth to twin. 


\section{References}

Anjam M. 2004. Development of Animal Husbandry, Constraints and Challenges in the Era of Regional Autonomy in South Kalimantan. Papers. Department of Animal Husbandry, South Kalimantan

Carruthers TD. 1986. Principles of hormone therapy, In: Current therapy in theriogenicology 2 . Morrow, DA (ed). WB. Saunders Co., Philadelphia.pp 2-13.

Fricke PM. 2003. Ovsynch, pre-synch, the kitchensynch: What's up with synchronization protocols? Publication of extension service. University of Winconsin. Madison. USA.

Hardjopranjoto S. 1995. Science infertility in cattle, Publisher Airlangga University Press. Surabaya.

Hardjosubroto W. 1994. Livestock Breeding Applications in the Field. PT. Scholastic Widiasarana Indonesia. Jakarta.

Hafez, B, and E.S.E. Hafez. 2000. Reproduction in farm animals. 7th Ed. Lea and Febinger, Philadelphia.p.96-107.

Ismudiono. 1999. Physiology of Animal Reproduction. Third Edition. Faculty of Veterinary Medicine, Airlangga University Surabaya.

Kirkpatrick BW. 2002. Management of twinning cow herd. J.Anim.Sci.80(E.Suppl.2):E14-E18.

Mac Millan KL. 1983. Prostaglandin response in dairy herd breeding programs. J. Vet. 31: 110-113.

Mee MO, JS Stevenson and RK Scoby. 1990. Influence of $\mathrm{GnRH}$ and timing of insemination relative to estrus on pregnancy rate of dairy cattle first service. J. Dairy Sci. 73:1500-1511.

Milvae RA, ST Hinckly and JC Carlson. 1996. Luteotropic and luteolytic mechanism in the bovine corpus luteum. J. Theriogenology. 45 : 1327-1349.

Moreira F De la Sota RI, T Diaz and WW Thatcher. 2000. Effect of day of the estrous cycle at the initiation of a timed artificial insemination protocol on reproductive responses in dairy heifers. J. Anim. Sci. 78:1568-1576.

Palengga NS and Putro PP. 2012. Serum progesterone profile in Bali cattle (bos indicus) treated with estrus synchronization using PGF2alpha. UGM xii, p89.

Okuda K, Gaona WA and Sato K. 1990. Effect of $\mathrm{GnRH}$ and PGF2Alpha on the reproductive performance in postpartum cows. Theriogenology 29:823-833.

Partodihardjo S. 1995. Reproduction in Animal. Veterinary faculty. Bogor Agriculture Institute. Bogor.
Putro PP. 1991.The treatment of anestrus and sub estrus in dairy cattle using a progesteronecontrolled internal drug release (CIDR) or a synthetic Gonadothropin Realizing Hormone (GnRH). Bulletin FKH UGM, December 1991.

Putro PP. 1994. Aplication of Estrus Ssynchronization Technique on the Buffalo and its problems. Bulletin.FKH-UGM Vol.XIII No.1-2 July-December 1994.

Putro PP, Prihatno SA, Junaidi A. 1993. Increased productivity of dairy cows with the use of a synthetic gonadotropin-releasing hormone (gonadorelin). Bulletin FKH UGM Vol.XII No 2 December 1993.

Putro PP, R Wasito, H Wuryastuti, S Indarjulianto. 2008. Ovulatory follicular dynamics after estrus with prostaglandin F2 alpha in dairy cows. Animal Science bulletin. Vol.32(3): 202-212, October 2008.

Purnomo. 1992. Analysis of categorical data. Airlangga University research institutes.Surabaya

Pursley JR, MO Mee and MC Wiltbank. 1995. Synchronization of ovulation in dairy cows using PGF2 $\alpha$ and GnRH. Theriogenelogy 44:915-923

Sosroamidjojo. 1980. Livestock and Working Animals. CV Yasaguna. Jakarta.

Schmith EJ, T Diaz, M Drost and WW Thatcher. 1996. Use of gonadotropin releasing hormone agonist or human chorionic gonadotropin for timed insemination in cattle. J. Anim. Sci. 74:10841091.

Suyasa N, P Dayu. 2011. Spreading Characteristics Twin Bali Cattle in Bali. In: Proceedings of National Seminar. BPTP Jogja

Stevenson JS, EP Call and RK Scoby. 1990. Double insemination and $\mathrm{GnRH}$ treatment of repeat breeding dairy cattle. J. Dairy Sci. 75:1766-1772.

Stevenson JS, JF Smith and DE Hawkins. 2000. Reproductive outcome for dairy heifer treated with combination of prostaglandin norgestomet and gonadotropin releasing hormone. J. Dairy Sci.83: 2008-2015

Toelihere MR. 1981. Physiology Reproduction for Cattle. Angkasa Bandung.

Tomaszewska MW, PIK Sutama and DT Chaniago. 1991. Reproduction, Behavior and Cattle production in Indonesia. PT. Gramedia Pustaka Utama . Jakarta.

Turman EJ, DB Laster, RE Renbarger and DF Stephens. 1971. Multiple births in beef cows treated with equine gonadotropin (PMS) and chorionic gonadotropin (HCG). J.Anim.Sci. 32:962-967.

Wenkoff M. 1986. Estrous synchronization in cattle. In: Current therapy in Therigenicology 2, 
Anastasia Sischa Jati Utami and I Nyoman Suyasa/Animal Production. 17(1):1-7, January 2015

Accredited by DGHE No. 81/DIKTI/Kep./2011. ISSN 1411-2027

Morrow, D,A. 2nd ed. WB Saunders Co., Philadelpia.

Williamson G and WJA Payne. 1993. An introduction to animal husbandry in the tropics. 3rd Edition. Longman Group Limited. London.
Yasa, IMR. 2001. Crop and Livestock Integration Studies on Dry Land Buleleng. In: Proceedings of National Seminar on Agricultural Technology Development Potential In Optimization Efforts Supporting Regional Autonomy. 365-367. 